\title{
Use of tulsi in oral and systemic diseases- A short review
}

\author{
Shaik Ali Hassan ${ }^{1 *}$, Sumit Bhateja ${ }^{2}$, Geetika Arora ${ }^{3}$ \\ ${ }^{1}$ Dental Surgeon, ${ }^{2} \mathrm{HOD},{ }^{3}$ Reader, ${ }^{1}$ Dept. of Oral Medicine, ${ }^{3}$ Dept. of Public Health Dentistry, ${ }^{1,2}$ Manav Rachna Dental \\ College, Faridabad, Haryana, ${ }^{3}$ Inderprastha Dental College \& Hospital, Ghaziabad, Uttar Pradesh, India
}

\section{*Corresponding Author: Shaik Ali Hassan}

Email: alishaikhassan@gmail.com

\begin{abstract}
Nature has presented on us a rich organic riches and various sorts of plants develop in various pieces of world. The therapeutic plants are generally utilized by the conventional restorative professionals for relieving different maladies. In customary frameworks of medication, various pieces of Ocimum sanctum Linn have been suggested for the treatment of different diorders. In this article we will tell about the use of tulsi in systemic and oral diseases.
\end{abstract}

Keywords: Tulsi, Cox-2, Candidiasis, Oral submucous fibrosis.

\section{Introduction}

The name 'Tulsi in Sanskrit signifies 'the unique one'. The holy basil, Ocimum sanctum L. (otherwise called Ocimum tenuiflorum) Tulsi, is famous for its strict and otherworldly sacredness, just as for its significant job in the conventional Ayurvedic and Unani arrangement of comprehensive wellbeing and natural prescription of the East. ${ }^{1}$ Although Tulsi is known as a general vitalizer and increments physical perseverance. The stem and leaves of blessed basil contain an assortment of constituents that may have organic movement.

\section{Use of tulsi in systemic diseases}

\section{Antidiabetic}

Ethanolic concentrate of $\mathrm{O}$. sanctum L. altogether diminishes the blood glucose, glycosylated hemoglobin and urea with an attendant increment in glycogen, hemoglobin and protein in streptozotocininstigated diabetic rodents. ${ }^{2}$

\section{Wound recuperating movement}

Ethanolic concentrate of leaves of O. sanctum L. builds the injury breaking quality, injury epithelialization process. The concentrate likewise altogether diminishes the counter mending exercises of dexamethasone in all twisted recuperating models. ${ }^{3}$ Ocimum sanctum L. might be helpful in the administration of unusual mending, for example, keloids and hypertropic scars. ${ }^{4}$

\section{Radio-defensive impact}

Uma Devi et $\mathrm{al}^{5}$ announced that two water-solvent flavonoids, Orientin (Ot) and Vicenin (Vc), disconnected from the leaves of O. sanctum L. give noteworthy security against radiation.

\section{Cancer prevention agent}

Watery concentrate of O. sanctum L. altogether builds the movement of hostile to oxidant chemicals, for example, superoxide dismutase and catalase level. ${ }^{6}$

\section{Antimicrobial}

Linoleic corrosive in O. sanctum L. fixed oil shows great antibacterial action against Staphylococcus aureus, Bacillus pumius and Pseudomonas aeruginosa. ${ }^{8}$ Geeta et $\mathrm{al}^{9}$ studied that the fluid concentrate of $\mathrm{O}$. sanctum $\mathrm{L}$ show wide zones of restraint contrasted with alcoholic concentrate against Klebsiella, E. coli, Proteus, S. aureus and Candida albicans when contemplated by agar dispersion strategy.

\section{Gastroprotective}

Home grown readiness containing O. Sanctum L. has been recommended to abbreviate the course of sickness, clinical side effects and biochemical parameters in patients experiencing viral hepatitis. It is useful in improving hunger. The juice of crisp leaves is utilized to treat loose bowels, dyspepsia, ceaseless fever and hemorrhage. ${ }^{10}$ 


\section{Inflamatory}

Singh ${ }^{11}$ in his investigation detailed that linoleic corrosive present in various sum in the fixed oil of various types of $\mathrm{O}$. sanctum $\mathrm{L}$. has the ability to square both the cyclooxygenase and lipoxygenase pathways of arachidonate digestion and could be answerable for the calming movement.

\section{Eye issue}

The leaf juice of O. sanctum L. alongside triphala is utilized in Ayurvedic drop readiness. It is utilized for glaucoma, waterfall, ceaseless conjunctivitis. ${ }^{10}$

\section{Renal issue}

Juice of tulsi leaves alongside nectar, whenever taken normally for a half year removes the renal stone through urinary tarct. ${ }^{11,12}$

\section{Mental issue}

Tulsi leaves are viewed as adaptogen (against stress). Considerable proof has aggregated that the herb's incredible general adaptogenic properties offer huge preventive and remedial potential concerning the pressure related degenerative ailments endemic to industrialized societies. ${ }^{13}$

\section{Skin issue}

Juice of tulsi leaves whenever applied locally is gainful in the treatment of ringworm and other skin diseases. $^{14}$

\section{Explicitly transmitted ailment}

Concentrate of $\mathrm{O}$. sanctum L. caused restraint of Neisseria gonorrhoeae clinical disconnects and WHO association strains. The movement is practically identical to penicillin and ciprofloxacin. ${ }^{15}$

\section{Tulsi use in oral health}

\section{Toothache}

Tulsi can go about as a COX-2 inhibitor like present day pain relieving due its noteworthy measure of eugenol. ${ }^{10}$

\section{Periodontal issue}

Powdered type of dried leaves of tulsi can be utilized for brushing teeth. It can likewise be blended in with assembled oil to make a glue and utilized as toothpaste. ${ }^{14}$ It can be utilized as mouthwash to treat different periodontal disorders. ${ }^{15}$ Mouthwash containing tulsi can fill in as a decent option in contrast to patients who wish to stay away from liquor (for example Xerostomics), sugar (for example Diabetics), any fake additives and fake hues in their mouthrinses.

\section{Anticariogenic impact}

Streptococcus mutan (S.mutan) is considered as the fundamental guilty party microorganisms liable for dental caries. An in vitro investigation directed by Pooja et al have evaluated different convergence of tulsi extricate against S.mutan and presumed that creation of tulsi remove at $4 \%$ has a greatest antrimicrobial potential. ${ }^{16}$

\section{Candidiasis}

the counter parasitic action of fundamental oil of Ocimum sanctum and its two segments for example eugenol and linalool against candida albicans and candida tropicalis and reasoned that linalool is progressively viable against candida.

\section{Oral submucous fibrosis}

The dynamic alkaloids present in Ocimum Sanctum for example Phenolic corrosive, Flavanoides, Glycocides, Linolols, Eugenol, Cineol can be utilized as antiperspirant, energizer, astringent, oedema reliever, pain relieving and haemostatic operator for the treatment of oral sub mucous fibrosis. Srivastva An et $\mathrm{al}^{17}$ have announced in their examination that a glue of $1 \mathrm{gm}$ tulsi powder and $1 \mathrm{gm}$ of turmeric powder in a glycerine whenever applied locally for 3-4 times each day can essentially expand mouth opening and diminish consuming sensation.

\section{Ulcer}

Tulsi have hostile to ulcerogenic just as ulcer mending properties because of its capacity to diminish corrosive emission and increment mucous discharge. The fixed oil of tulsi was found to have critical enemy of ulcer action against medicate instigated just as pressure prompted ulceration in test models. ${ }^{18}$ 


\section{Source of Funding}

None.

\section{Conflict of Interest}

None.

\section{References}

1. Pattanayak P, Behera P, Das D, Panda SK. Ocimum sanctum Linn. A reservoir plant for therapeutic applications: An overview. Phcog Rev 2010;4:95-105.

2. Narendhirakannan RT, Subramanian S, Kandaswamy M. Biochemical evaluation of antidiabetogenic properties of some commonly used Indian plants on streptozotocininduced diabetes in experimental rats. Clin Exp Pharmacol Physiol 2006;33:1150-7.

3. Udupa SL, Shetty S, Udupa AL, Somayaji SN. Effect of Ocimum sanctum Linn on normal and dexamethasone suppressed wound healing. Indian J Exp Biol 2006;44:4954.

4. Shetty S, Udupa S, Udupa L, Somayaji N. Wound healing activity of Ocimum sanctum Linn with supportive role of antioxidant enzymes. Indian J Physiol Pharmacol 2006;50:163-8.

5. Uma Devi P, Ganasoundari A, Vrinda B, Srinivasan KK, Unnikrishnan MK. Radiation protection by the Ocimum flavonoids orientin and vicenin: Mechanisms of action. Radiat Res 2000;154:455-60.

6. Gupta S, Mediratta PK, Singh S, Sharma KK, Shukla R. Antidiabetic, antihypercholesterolaemic and antioxidant effect of Ocimum sanctum (Linn) seed oil. Indian J Exp Biol 2006;44:300-4.

7. Trevisan MT, Vasconcelos Silva MG, Pfundstein B, Spiegelhalder B, Owen RW. Characterization of the volatile pattern and antioxidant capacity of essential oils from different species of the genus Ocimum. J Agric Food Chem 2006;54:4378-82.

8. Singh S, Malhotra M, Majumdar DK. Antibacterial activity of Ocimum sanctum L. fixed oil. Indian J Exp Biol 2005;43:835-7.
9. Geeta, Vasudevan DM, Kedlaya R, Deepa S, Ballal M. Activity of Ocimum sanctum (the traditional Indian medicinal plant) against the enteric pathogens. Indian $J$ Med Sci 2001;55:434-8.

10. Bhateja S, Arora G. Therapeutic benefits of holy Basil (Tulsi) in general and oral medicine: A review. Int J Res Ayur Pharm 2012;3(6):761-4.

11. Singh S. Comparative evalution of antiinflammatory potential of fixed oil of different species of Ocimum and its possible mechanism of action. Indian J Exp Biol 1998;36:1028-31.

12. Karthikeyan K, Ravichandran P, Govindasamy S. Chemopreventive effect of Ocimum sanctum on DMBAinduced hamster buccal pouch carcinogenesis. Oral Oncol 1999;35:112-9.

13. Prashar R, Kumar A, Hewer A, Cole KJ, Davis W, Phillips DH. Inhibition by an extract of Ocimum sanctum of DNAbinding activity of 7,12-dimethylbenzaanthracene in rat hepatocytes in vitro. Cancer Lett 1998;128:155-60.

14. MP Bhattathiry.15 benefits of Holy Basil (Tulsi). [cited 2015 Jan 9] Available from http:// www. hinduism. com.

15. Shokeen P, Ray K, Bala M, Tondon V. Prelimnary studies on activity of Ocimum sanctum, Drynaria quercifolia, and Annona squamosa against Neisseria gonorrohoeae. Sex Transm Dis 2005;32:106-11.

16. Panda S, Kar A. Ocimum sanctum leaf extract in the regulation of thyroid function in the male mouse. Pharmacol Res 1998;38:107-10.

17. Gupta SK, Prakash J, Srivastva S. Validation of claim of Tulsi, Ocimum Sanctum Linn as a medicinal plant. Indian J Experimental Biology 2002;40(7):765-73.

18. Haffajee AD, Yaskell T, Socransky SS. Antimicrobial effectiveness of an herbal mouthrinse compared with an essential oil and a chlorhexidine mouthrinse. J Am Dent Assoc 2008;139(5):606-11.

How to cite this article: Hassan SA, Bhateja S, Arora G. Use of tulsi in oral and systemic diseases- A short review. J Paediatr Nurs Sci 2019;2(4):105-7. 